\title{
EL PROCESO DE ENSEÑANZA APRENDIZAJE PARA CÁTEDRAS NUMEROSAS EN CARRERAS TÉCNICAS: "UNA EXPERIENCIA INNOVADORA DE LA CÁTEDRA DE SOCIOLOGÍA Y EXTENSIÓN RURAL"
}

\author{
Speziale, J. ${ }^{1}$; Elz, R. O. ${ }^{2}$; Sanchez, S. G. ${ }^{1}$; Sandoval, P. de los M. ${ }^{1}$; \\ Bürgi, N. L. ${ }^{3}$; Rotondi, F. A. ${ }^{1}$; Bergagna, D. ${ }^{1} ; \&$ LUnA, J. L. ${ }^{1}$
}

\begin{abstract}
RESUMEN
La Cátedra de Sociología y Extensión Rural de la Facultad de Agronomía y Veterinaria de la Universidad Nacional del Litoral desarrolló una metodología de enseñanza aprendizaje, denominada Cursado Intensivo, que significó mejorar sustancialmente la comprensión y enseñanza de los contenidos sociales por parte de los alumnos de carreras eminentemente técnicas, superándose el aprendizaje como instrucción, y lográndolo por elaboración y reelaboración mediatizada por la experiencia inter y extrapersonal. Esta práctica se utilizó fundamentalmente con matrículas de no más de cuarenta alumnos, planteándose entonces la posibilidad de realizarla con cátedras mas numerosas, como las que cursan en la Facultad de Veterinaria, ya que la metodología presentaba algunos inconvenientes para su utilización en estas circunstancias. En el desarrollo de estrategias metodológicas se buscó como marco el que sostiene a la investigación orientada a la práctica educativa, privilegiando la decisión y el cambio. La investigación-evaluativa y la investigación-acción, brindaron elementos para el diseño de los instrumentos intervinientes y a la vez delimitaron el enfoque teórico desde donde se construyó el paradigma investigativo. Se utilizaron elementos conceptuales y metodológicos de la Educación a Distancia, tales como la producción de materiales impresos y la formación de tutores, que intervinieron como principales propuestas metodológicas para el logro de los resultados esperados. Se modificó sustancialmente la forma de dictado con la intervención más activa del alumno y la complementación con tutores y docentes. Con esta estrategia didáctica se obtuvieron resultados altamente significativos.
\end{abstract}

Palabras clave: Cátedras numerosas, Cursado intensivo, Enseñanza, Aprendizaje relevante, Carreras técnicas.

1.- Cátedra de Sociología y Extensión Rural. Facultad de Ciencias Agrarias, Universidad Nacional del Litoral. Ciudad Universitaria. Paraje El Pozo. (3000) Santa Fe.

2.- Cátedra de Formación Humanística. FCA (UNL).

3.- Cátedra de Introducción a la Agronomía. FCA(UNL).

Manuscrito recibido el 20 de febrero de 2003 y aceptado para su publicación el 23 de abril de 2003. 


\section{SUMMARY}

The process of teaching-learning for numerous classes in technical careers: "An innovative experience of the sociology and rural extension class»

The Rural Extension and Sociology Cathedra of Agronomy and Veterinary College of the Litoral National University, had developed a teaching learning methodology denominated Intensive Studied. This meant to improve substantially the understanding and acceptance of the social contents for the students of eminently technical careers, being overcome the learning by instruction, and achieving it for elaboration and incorporated re-elaboration by the inter and extra- tutors personal experience. This practice was fundamentally used with registrations not higher than forty students, thinking about the possibility to carry out it with numerous courses, as those that study in the Veterinary College, since the methodology presented some inconveniences for its use in these circumstances. In the development of methodological strategies, it was looked like mark the one that sustains the investigation guided to educational practice, privileging the decision and change. The evaluative and the action investigation, offered elements for the design of the interveners instruments and at the same time defined the theoretical focus from where the investigative paradigm was built. Conceptual and methodological elements were used from the Distance Education, such as the production of printed materials and the formation of tutors that intervened as main methodological proposals for the achievement of the prospective results. It was substantially modified the dictation form, with a more active intervention of the student and the complementation with professors and tutors. With this didactic strategy, highly significant results were obtained.

Key words: Numerouses Cathedras, Intensive Classes, Excellent teaching-learning, Technical careers. 